\title{
Viator vitreocola gen. et sp. nov. (Stylonematophyceae), a new red alga on drift glass debris in Oregon and Washington, USA
}

\author{
Gayle I. Hansen ${ }^{1, *}$, John A. West ${ }^{2}$, Hwan Su Yoon ${ }^{3}$, Christopher D. Goodman ${ }^{2}$, Susan \\ Loiseaux-de Goër ${ }^{4}$ and Giuseppe C. Zuccarello ${ }^{5}$ \\ ${ }^{1}$ Oregon State University, HMSC-EPA, 2111 SE Marine Science Drive, Newport, OR 97365-5260, USA \\ ${ }^{2}$ School of BioSciences, University of Melbourne, Parkville, VIC 3010, Australia \\ ${ }^{3}$ Department of Biological Sciences, Sungkyunkwan University, Suwon 16419, Korea \\ ${ }^{4} 11$ Rue des Moguérou, 29680 Roscoff, France \\ ${ }^{5}$ School of Biological Sciences, Victoria University of Wellington, PO Box 600, Wellington, 6140, New Zealand
}

A new encrusting red alga was found growing abundantly on glass debris items that drifted ashore along the coasts of Oregon and Washington. These included discarded fluorescent tubes, incandescent light bulbs, capped liquor bottles, and ball-shaped fishing-net floats. Field collections and unialgal cultures of the alga revealed that it consisted of two morphological phases: a young loosely aggregated turf and a mature consolidated mucilaginous crust. The turf phase consisted of a basal layer of globose cells that produced erect, rarely branched, uniseriate to multiseriate filaments up to $500 \mu \mathrm{m}$ long with closely spaced cells lacking pit-plugs. These filaments expanded in size from their bases to their tips and released single cells as spores. At maturity, a second phase of growth occurred that produced a consolidated crust, up to $370 \mu \mathrm{m}$ thick. It consisted of a basal layer of small, tightly appressed ellipsoidal-to-elongate cells that generated a mucilaginous perithallial matrix containing a second type of filament with irregularly spaced cells often undergoing binary division. At the matrix surface, the original filaments continued to grow and release spores but often also eroded. Individual cells, examined using confocal microscopy and SYBR Green staining, were found to contain a central nucleus, a single highly lobed peripheral chloroplast without a pyrenoid, and numerous chloroplast nucleoids. Morphological data from field and culture isolates and molecular data ( $r b c \mathrm{~L}, p s b \mathrm{~A}$, and $\mathrm{SSU})$ show that this alga is a new genus and species which we name Viator vitreocola, "a traveller on glass."

Key Words: DNA staining; glass debris; phylogenetics; $p s b \mathrm{~A} ; r b c L$; Rhodophyta; SSU; Stylonematophyceae

\section{INTRODUCTION}

The increasing accumulation of debris in the oceans is a global problem. Along the outer coast of Washington and Oregon (USA), floating debris frequently washes ashore, carried from both Asian and eastern Pacific areas by the North Pacific and Davidson Currents. The tide- pools and beaches in this area are popular tourist attractions, so it is important to the local residents that they are kept clean. Volunteer groups in both states (SOLVE and GRGG) conduct bi-annual or more frequent beach cleanups where they collect, remove and quantify the types of
(9) This is an Open Access article distributed under the terms of the Creative Commons Attribution Non-Commercial License (http://creativecommons.org/licenses/by-nc/3.0/) which permits unrestricted non-commercial use, distribution, and reproduction in any medium, provided the original work is properly cited.
Received February 19, 2019, Accepted May 20, 2019

*Corresponding Author

E-mail: hansengi@outlook.com

Tel: +1-541-265-4061, Fax: +1-541-867-4049 
debris arriving and occasionally provide specific items to scientists on request. Since the clean-ups first began in Oregon in 1984 (https://www.solveoregon.org/springbeach-cleanup-faq\#1) and Washington in 2002 (https:// www.facebook.com/pg/GrassRootsGarbageGang), sporadic occurrences of local and distant (often Asian) debris have been observed (R. Lewis personal communication). During 2012-2016, considerable quantities of debris arrived on shore from the 2011 Great Tohoku Earthquake and Tsunami (Carlton et al. 2017). Since this time, debris has been less abundant but continues to litter the beaches (personal observations).

In the spring of 2016, while investigating the fouling algal biota on Japanese tsunami debris (Hansen et al. 2017, 2018), we discovered an unusual pink crust coating the larger $(>12 \mathrm{~cm})$ white plastic debris items that washed ashore. Initially the identity of this species was unknown, but it appeared to be a member of the Stylonematophyceae, a structurally simple group of red algae (Kim and Kim 2011) that contains, to date, 18 genera (Guiry and Guiry 2019). Through culture work and sequencing, we found that the alga was a new genus and species in this class and named it Tsunamia transpacifica West et al. (West et al. 2016). In addition, a second closely related species was identified based on molecular data alone. This latter species, designated as uncultured Stylonematales sp., was initially thought to represent the $r b c \mathrm{~L}$ sp. 2 group of that study (West et al. 2016, Table 1).

In our search for additional specimens of T. transpacifi$c a$ and the uncultured Stylonematales sp., we discovered yet another unknown pink to pale red crust, but rather than being on plastic debris, this crust was found only on glass debris. Although similar in colour, the new crust was softer, thicker and more fragile than T. transpacifica. It was quite rare, but from 2013 to 2018, we were able to obtain enough material of the crust on glass to carry out a thorough morphological, molecular and phylogenetic investigation and to determine that it was also a new genus and species in the Stylonematophyceae.

\section{MATERIALS AND METHODS}

\section{Collections}

To obtain samples of the new crust, we enlisted the help of the volunteer beach cleaning groups in Oregon and Washington. These individuals sent glass debris items to us on request and also allowed us to search through their refuse collections for other items carrying the pale red crusts. With their assistance, we were able to obtain 10 collections (13 items) of glass debris carrying the rare crust (Supplementary Table S1).

\section{Processing field collections in Oregon}

Once the collections were obtained, the debris objects were photographed, and samples of the crusts were scraped from the debris with a razor blade and prepared for study. For anatomical study, small fragments of the material were preserved in 5\% formalin in seawater, sectioned by hand with a razor blade, \pm stained with $1 \%$ aniline-blue-acid, and then mounted on a slide in $40 \%$ white corn syrup for microscopic observation with a Zeiss Axioskope (Carl Zeiss AG, Jena, Germany) equipped with a Leica DFC 290 camera (Leica Camera AG, Wetzlar, Germany). For DNA sequencing, the fragments were placed into silica gel in zip-lock bags and mailed to G. C. Zuccarello and H. S. Yoon for analysis. For culturing, the field material was first placed into seawater media in Newport, Oregon, to be certain of its viability. After rinsing in sterile seawater, $5 \mathrm{~mm}$ strips of each sample were placed into $10 \mathrm{~cm}$ petri dishes lined with sterile coverslips, flooded with an enriched seawater solution (dilute Provasoli's or F/2) (Andersen 2005), and then transferred to $11^{\circ} \mathrm{C}$ and a $16: 8$ light-dark cycle for two weeks of observation. The material began to release spores immediately and the early release and germination stages were photographed. With viability confirmed, healthy strips of material were mailed to J. West.

\section{Processing specimens for long-term cultivation and study}

In Australia (at the West lab), unialgal cultures were prepared by placing single algal strips into a $35 \mathrm{~mm}$ well of two 6-well microculture plates, each containing $5 \mathrm{~mL}$ of quarter-strength modified Provasoli's medium (West and McBride 1999) with $\mathrm{GeO}_{2}$ and Na Penicillin G added to supress diatom and cyanobacterial growth. The plates were sealed with tape and placed in $18-20^{\circ} \mathrm{C}$ in a $10: 14$ lightdark cycle with 2-4 $\mu \mathrm{mol}$ photons $\mathrm{m}^{-2} \mathrm{~s}^{-1} \mathrm{LED}$ cool-white lighting. These were monitored at two-weeks intervals for recovery, growth, and reduction of contaminants by excising $1 \mathrm{~mm}$ pieces of material with micro-forceps and examining them under a Zeiss stereomicroscope equipped with KL1500 LCD lighting (Schott AG, Mainz, Germany) and then a Zeiss GFL compound microscope (both microscopes: Carl Zeiss AG). Clean segments were then transferred to similar 6-well plates or to $50 \times 70 \mathrm{~mm}$ 
glass dishes containing $22 \mathrm{~mm}$ coverslips with the same medium and conditions.

\section{DNA staining}

To follow the germination stages in unialgal culture more precisely, specific DNA staining and high-resolution microscopy were employed. Initially, coverslips containing actively growing sporelings were transferred to a higher light intensity (10-15 $\mu \mathrm{mol}$ photons $\mathrm{m}^{-2} \mathrm{~s}^{-1} \mathrm{LED}$ lighting) for one week until they became multicellular. Then the coverslip specimens were preserved by one of two methods: (1) immersing in $4 \%$ paraformaldehyde fixative (Electron Microscopy Sciences, Hatfield, PA, USA) for $10 \mathrm{~min}$ or (2) microwaving material placed in $15 \mathrm{~mL}$ of distilled water in a plastic petri dish for 3 successive 3-4 s doses of 800 Watts (to avoid boilover). They were then rinsed in seawater and stained with $1: 10,000$ SYBR Green (Thermo Fisher, Waltham, MA, USA) for 5 min. Following staining, coverslips were washed in milliQ water, mounted under a $22 \mathrm{~mm}$ coverslip on a slide in AntiFade DAKO fluorescent mounting media (Agilent, Santa Clara, CA, USA), and sealed with VALAP (1 : $1: 1$ mixture of paraffin, lanolin and Vaseline melted on a hotplate at $40^{\circ} \mathrm{C}$ ). Imaging was done with a Nikon $\mathrm{C} 2$ confocal microscope (Japan, the Biological Optical Microscopy Platform, University of Melbourne). Deconvolution and image reconstruction were done with NIS Elements software (Nikon, Tokyo, Japan).

\section{DNA extraction and sequencing}

DNA was extracted from silica gel dried field samples or cultured material using a modified CTAB buffer procedure (Zuccarello and Lokhorst 2005) with 1\% polyvinylpolypyrrolidone added to the extraction buffer.

Three genetic regions were used to determine phylogenetic relationships and sample identity:

(1) Amplification and sequencing of the plastid-encoded large subunit of the ribulose-1,5-bisphosphate carboxylase / oxygenase gene ( $r b c \mathrm{~L}$ ) used amplification primers presented in Freshwater and Rueness (1994). This data set incorporated sequences from GenBank and was used to compare the new samples with other Stylonematales. The polymerase chain reaction (PCR) procedure followed Zuccarello et al. (2002).

(2) Partial nuclear-encoded small ribosomal RNA gene (SSU) (between primers G04 and J04) (Saunders and Kraft 1994) (approximately $800 \mathrm{bp}$ at the $3^{\prime}$ end of the SSU) can compared to other Stylonematales. The PCR procedure followed Broom et al. (1999).

(3) The plastid-encoded psbA (photosystem II reaction center protein D1) gene was amplified using the primers described in Yoon et al. (2002).

New sequences were assembled and edited in Geneious ver. 10 (https://www.geneious.com). MAFFT alignments were implemented in Geneious.

Bayesian inference was performed with MrBayes v.3.2 (Ronquist and Huelsenbeck 2003, Ronquist et al. 2012). Analyses consisted of two independent simultaneous runs of one cold and three incrementally heated chains, and $3 \times 10^{6}$ generations with sampling every 1,000 generations. A "burn-in" of $5 \times 10^{5}$ generations was used and 25,000 trees were saved to make the consensus tree. maximum-likelihood (ML) analyses were implemented using IQ-tree (Trifinopoulos et al. 2016). IQ-tree was used to select the molecular evolution models (Modelfinder) and construct a ML trees with 1,000 bootstrap approximations. Both single gene trees and a concatenated supermatrix tree were used for analysis. Alignments were partitioned by codons, and by gene also where appropriate. Models were selected using the Bayesian Information Criterion criterion and are presented in Supplementary Table S2. The Porphyridiales (Porphyridium aerugineum Geitler, Flintiella sanguinaria Ott) were used as an outgroup.

\section{RESULTS}

\section{Collections of field material}

The 10 collections of debris with the alga on glass were found mostly along the drift-line of sandy beaches from March 2013 to December 2018. The types of glass debris varied and included fluorescent light tubes, incandescent light bulbs, capped liquor bottles and ball-shaped fishing-net floats (Fig. 1). All the items were entire and could float. Many appeared to have been on the beach for a few days, and, on these, the crusts were dry but still in good enough condition for anatomical study and sequencing. Only one debris item bore a crust that was living and healthy enough for long-term culture. This was a fluorescent tube from Otter Crest, OR (collected Mar 25, 2018). Material from this collection was sent to Australia to set up unialgal cultures (JAW 4881) for investigations of development and also to establish a pure-culture holotype for the new species. 

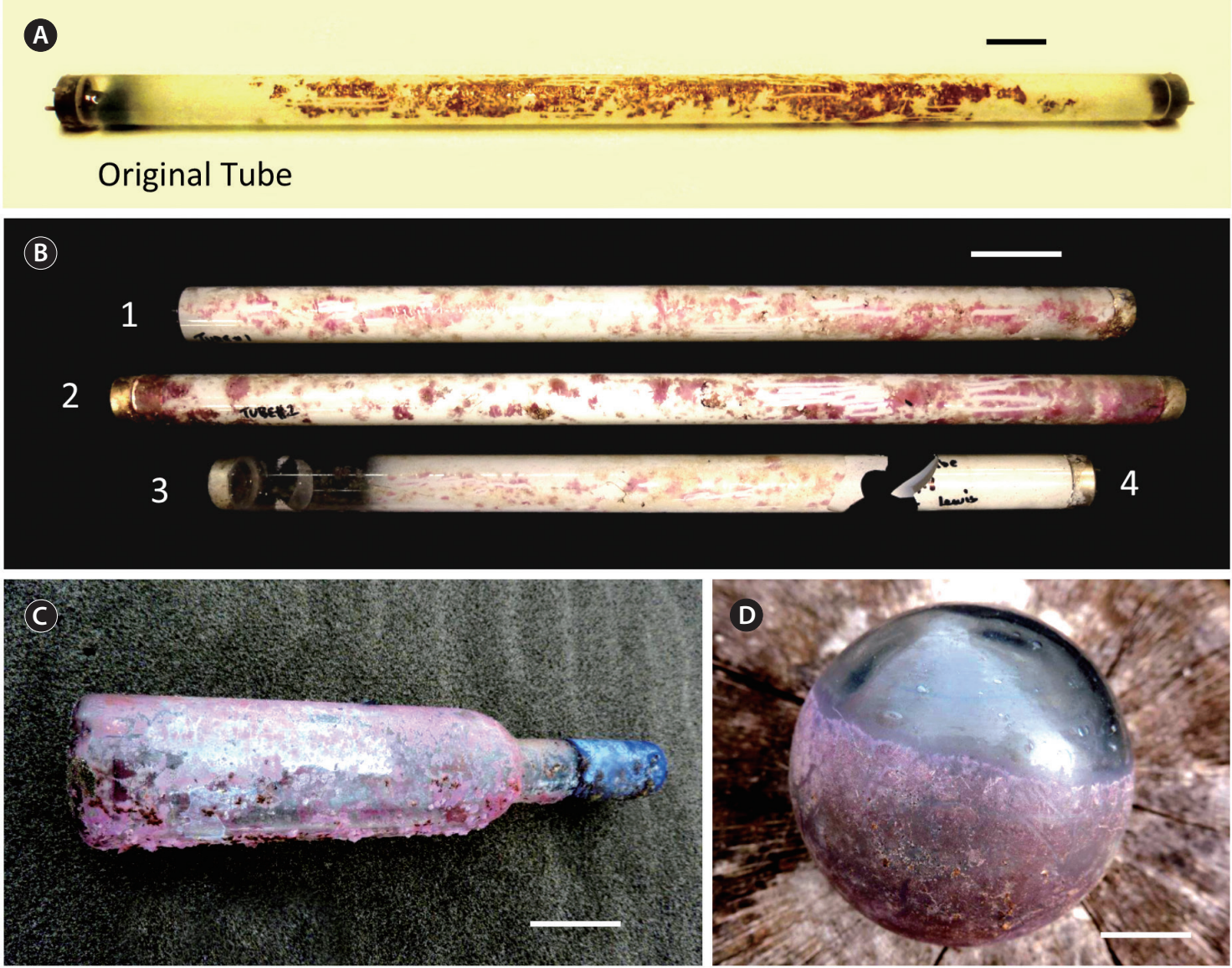

(E)

$\boldsymbol{F}$
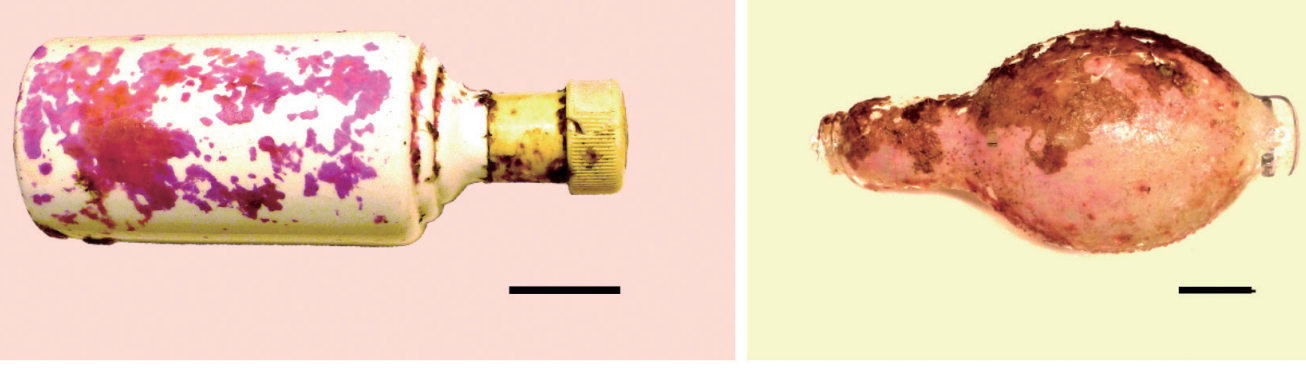

Fig. 1. Pale red Stylonematophycean thalli on various glass debris. (A) From Otter Crest, OR: Original fluorescent tube from which cultures were taken. (B-E) From Long Beach, WA: (B) Fluorescent tubes 1-4, (C) Russian vodka bottle, (D) Japanese glass fishing-net float, (E) White liquor bottle. (F) From Nye Beach, OR: halide lightbulb. Scale bars represent: $A, 3 \mathrm{~cm} ; \mathrm{B} \& \mathrm{C}, 5 \mathrm{~cm} ; \mathrm{D}-\mathrm{F}, 4 \mathrm{~cm}$.

\section{Morphological observations of field collected specimens}

On the debris items, the soft pale red crustose thalli occurred in irregular patches and in large confluent areas on the surface of the glass (Fig. 1A-F). They varied somewhat in thickness and in colour but otherwise appeared superficially very similar. However, when examined with a microscope, they were found to consist of two very different morphological forms. It was only after identification based on sequence data that we discovered they were actually a single species. The species appeared to be in two different phases of development that were age related: (1) a juvenile turf phase (Fig. 2) and (2) a more mature mucilaginous crustose phase (Fig. 3). Both phases were composed of filaments lacking pit-plugs. 

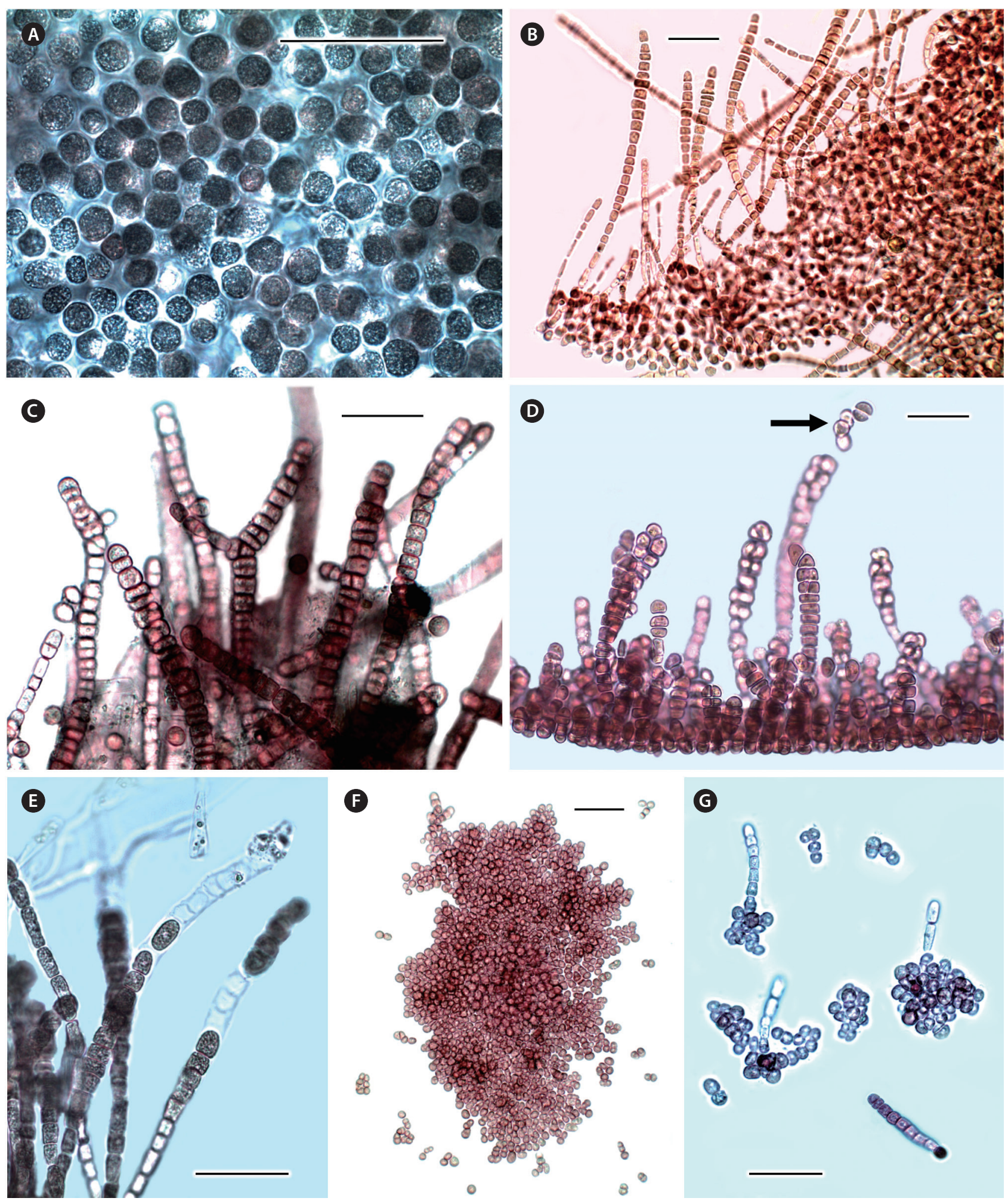

$\boldsymbol{F}$

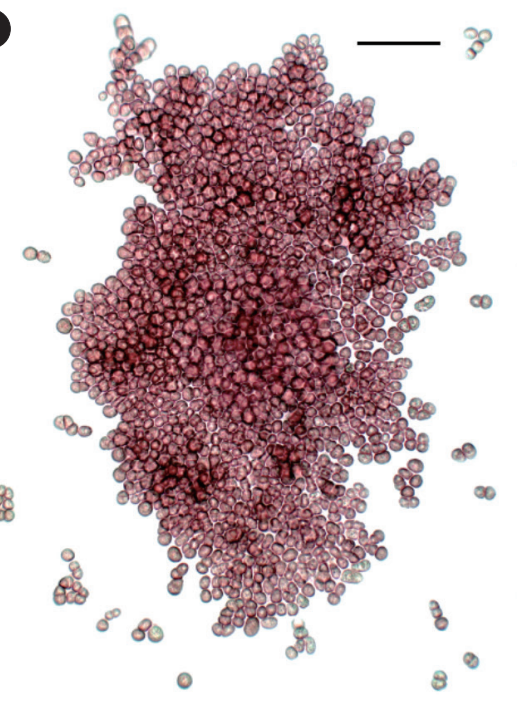

$\boldsymbol{G}$

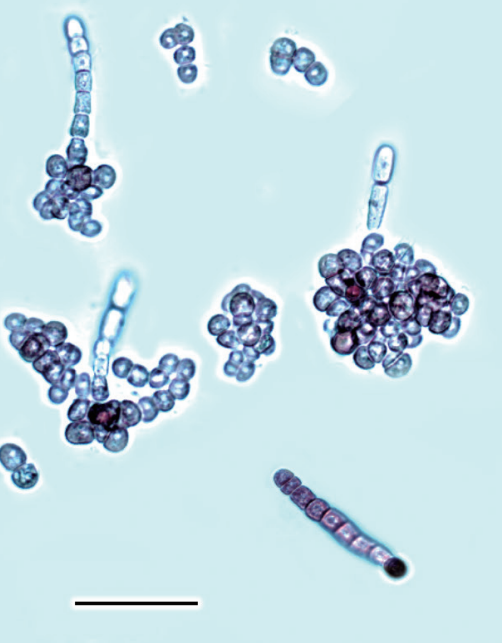

Fig. 2. Turf phase anatomy. (A-C, E \& F) Material from original fluorescent tube found at Otter Crest, OR, Mar 25, 2018. (D) Material from incandescent bulb found at Long Beach, WA, Dec 19, 2018. (A) Young clustered unicells. (B) Developing turf with erect filaments lacking pit-plugs. (C \& D) Erect filaments becoming bi to multiseriate and occasionally branched, with a few released spores (arrow in D). (E) Filaments with empty cells after spore release. (F) Aggregation of spores released from field material in culture. (G) Unipolar spore germination and initial erect filaments. Scale bars represent: A, $20 \mu \mathrm{m} ; \mathrm{B}-\mathrm{G}, 50 \mu \mathrm{m}$. 

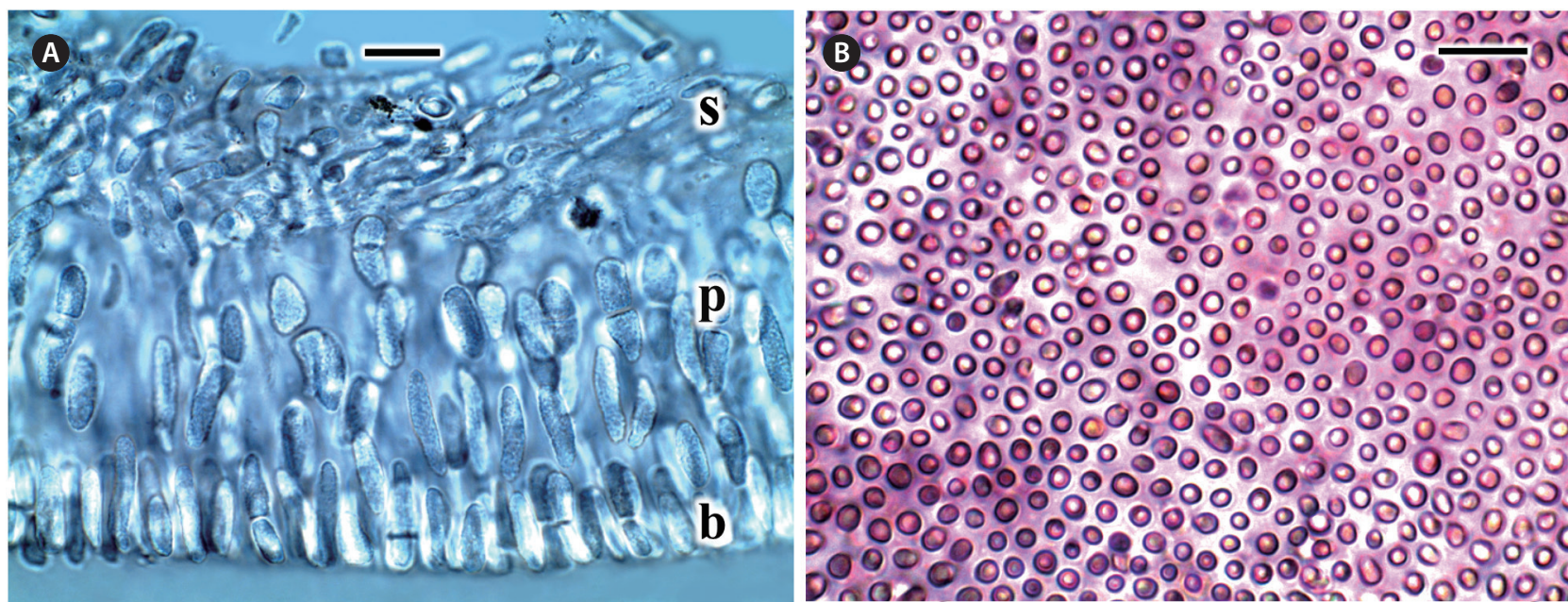
$000000.0000000000 \% 0$ $600 \% \% 0000000000000 \%$ $000.00 \% 00 \% 0000 \% 00 \%$ $00 \% 000000000000$ $00 \%$ \% $00 \% 0 \% 0: 0 \% 0 \%$ $0 \% \% 0 \% 00 \% 0 \% 0 \%$ $000 \% 000 \% 0 \% \%$ $0000 \% 0 \% 000000000$ 0000000000000000000 00000000008090000000 0.00 00000 00100000000 $200000000000 \% 00000000$ 10000000000000800000090

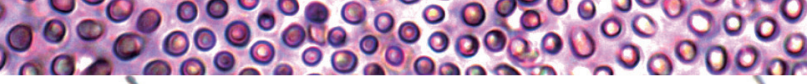
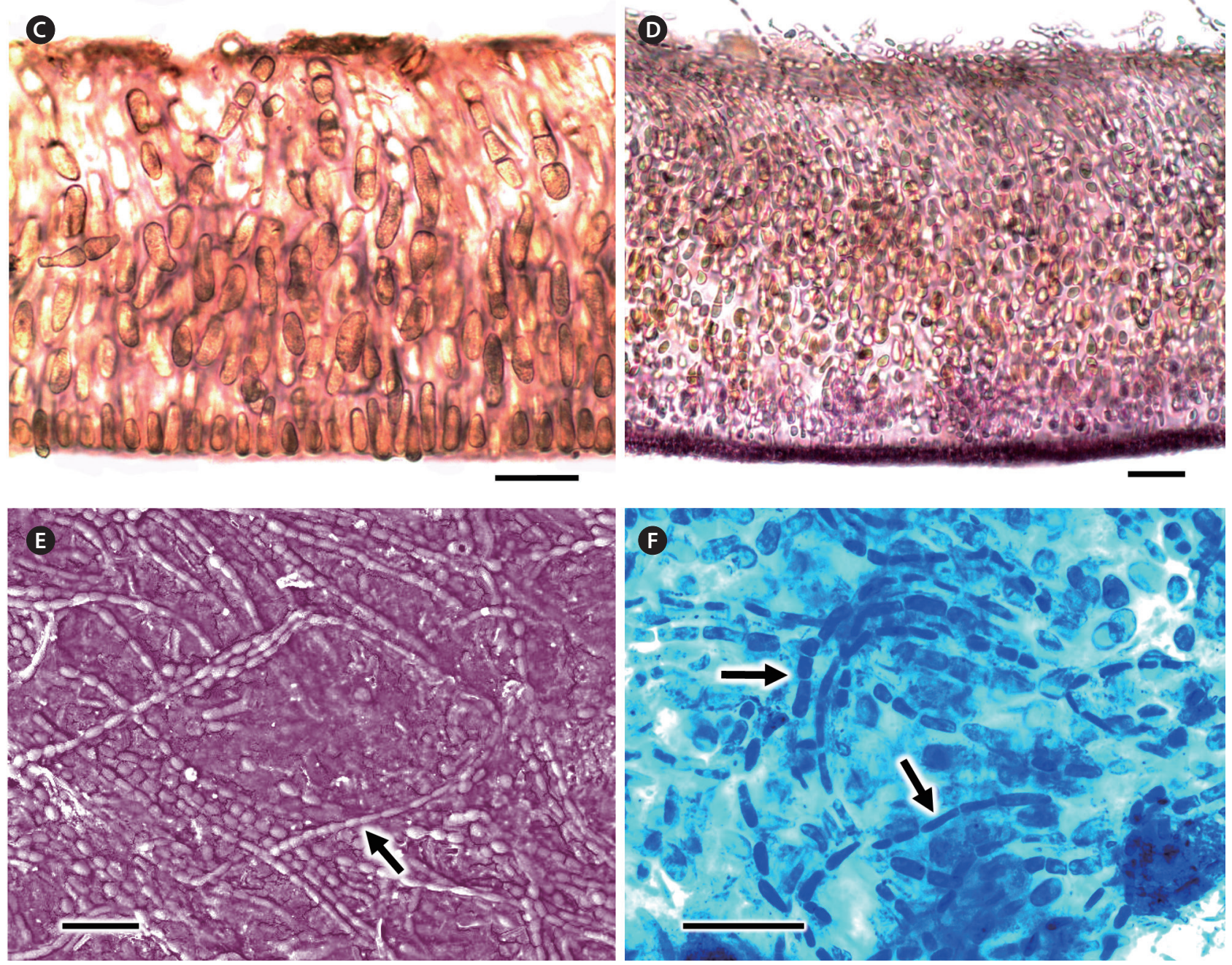

Fig. 3. Crust phase anatomy. (A-F) Material from fluorescent tubes found at Long Beach, WA, May 14, 2018. (A) Transverse section of a young crust with 3 layers: s, surface layer with free filaments; p, perithallial layer; b, basal layer with ellipsoidal to elongate cells. (B) Bottom view of the crust observed through glass showing small basal cells. (C \& D) Transverse sections. (C) Older crust with surface filaments eroded above the mucilage layer. (D) Mature crust with dense perithallial and sparse surface filaments. (E \& F) Top views of the crust. (E) Scanning electron microscope photo of the surface showing superficial filaments (arrow). (F) Aniline blue-acid staining revealing long surface filaments (arrows). Scale bars represent: A \& B, $20 \mu \mathrm{m} ; \mathrm{C}-\mathrm{F}, 50 \mu \mathrm{m}$. 
The juvenile turf phase. Microscopic examination of the alga on the original Otter Crest tube (Fig. 1A) revealed colonies of clustered unicells, possibly maturing spores, 8-12 $\mu \mathrm{m}$ in diameter (Fig. 2A), and also older patches of cells that had divided to form a turf of small tightly appressed basal cells (4-7 $\mu \mathrm{m}$ wide) supporting a lawn of erect filaments reaching 300-500 $\mu \mathrm{m}$ in height (Fig. 2B). The erect filaments were uniseriate and 4-7 $\mu \mathrm{m}$ in diameter near their bases but often increased in size upward reaching $15 \mu \mathrm{m}$ in diameter near their rounded tips. They were occasionally branched and frequently became biseriate or multiseriate (Fig. 2C \& D). When placed into culture under $16: 8$ long day conditions, the filaments began releasing whole cells as spores (Fig. 2E), often producing dense clusters of spores that settled in the culture dishes (Fig. 2F). This initial spore release occurred soon after the thalli were placed into media after remaining dry on the beach for several days. The newly released spores were 8-12 (15) $\mu \mathrm{m}$ in diameter and quickly attached to the surface. Unipolar germination occurred, and the cells divided to form small irregular colonies that began to initiate erect filaments by the end of week 2 (Fig. 2G).

The mucilaginous crustose phase. Only a few months after finding the original tube, four fluorescent tubes were collected at Leadbetter Point on the Long Beach Peninsula (WA) on May 14, 2018 that also contained patches of the new crust (Fig. 1B). Although similar in habit, a microscopic examination of these patches did not reveal the previously described turf form of the alga. Instead, they were composed of a consolidated crust, up to $370 \mu \mathrm{m}$ thick, with a very unusual anatomy.

In transverse section (Fig. 3A), three parts to the crust were evident: (1) a base consisting of a single layer of small tightly appressed ellipsoidal to elongate cells, (2) a perithallial layer of erect and often branched filaments immersed in a gelatinous matrix, and (3) a surface layer of free filaments outside the matrix. The basal cells were thick-walled, $5 \mu \mathrm{m}$ in diameter, and closely aligned along the glass substrate (Fig. 3A \& B). There was no indication of any rhizoid development. The perithallial layer consisted of short erect filaments and binary cells (cells with a central division) that varied in density and branching but were held together by a thick gelatinous matrix (Fig. $3 \mathrm{C}$ ). The cells were ovoid to elongate in shape, $5-10 \mu \mathrm{m}$ in diameter, and were often seen dividing. Branching was most abundant in the middle to lower portions of this layer and appeared to increase in the thicker crusts (Fig. 3D). Near the top of the crust, the gelatinous layer ended, but the filaments continued to extend upward forming the surface layer of loose filaments, up to 15 or more cells in length. Easily seen in surface view (Fig. 3E \& F), the cells in these filaments were 10-20 $\mu \mathrm{m}$ long and 4-12 $\mu \mathrm{m}$ in diameter, often narrower than those in the perithallus. Exposed to weathering, the surface filaments were frequently procumbent (Fig. 3A) and even worn away (Fig. 3C).

Transition from the turf to the crust phase. In November and December of 2018, new debris items, including incandescent bulbs, were found in both Oregon and Washington carrying more material (Supplementary Table S1). These collections were particularly interesting because they included stages that revealed the development of the crust. Several of the specimens bore long surface filaments and were initially thought to be the turf phase. However, on sectioning, they were found to also contain short mucilaginous crusts near their base (Fig. $4 \mathrm{~A} \& \mathrm{C})$. On careful examination, it was discovered that the surface filaments remained attached to the top of the mucilaginous crust (Fig. 4A \& C, short arrows), but that the crust itself was developing below this from the basal layer of cells. These basal cells were cleaving off irregularly spaced cells and short filaments that were often undergoing binary division, all within the mucilaginous matrix (Fig. 4A \& B, long arrows). While this was occurring, the surface filaments were pushed upward, and occasionally became multiseriate and released spores as was observed in younger turf phase thalli. As these filaments withered and the crust developed, vertical striations in the mucilaginous matrix became apparent (Fig. 4D). In some samples the striations could clearly be seen as vertical columns (Fig. $4 \mathrm{E} \& \mathrm{G}$ ). In periclinal section, it was obvious that they were mucilaginous tubes that surrounded the perithallial cells (Fig. 4F) before branching occurred (Fig. 3C \& D). Further observations revealed that the tubes were subtended by and apparently generated by the basal meristematic layer of cells (Fig. 4G).

Additional debris items carrying the new alga. Although most of our studies were carried out on material derived from fluorescent and incandescent light bulbs, we also found the pale red crust on various capped liquor bottles and on Japanese ball-shaped fishing-net floats (Fig. 1C-E, Supplementary Table S1). On the liquor bottles, the crust was soft, thick and pink in colour and superficially resembled a coralline alga, but, in each case, the thalli bore the characteristic anatomy of the crust phase. The few ball-shaped fishing-net floats that we were able to examine contained the turf phase of the alga. All of the balls were pale green to aqua in colour and hand-blown with a sealing button on one end, typical of most of those manufactured in Japan. They were $10 \mathrm{~cm}$ 

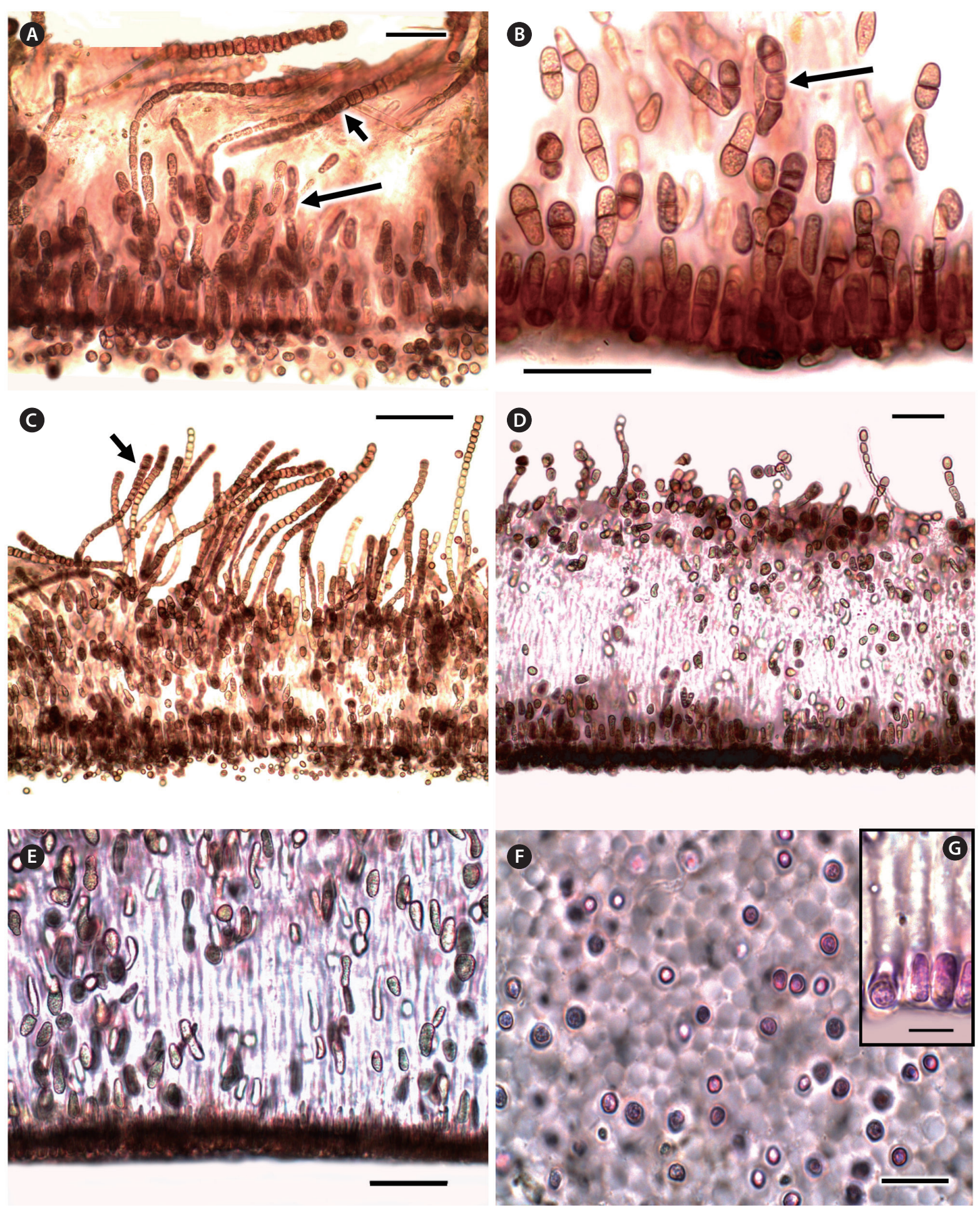

Fig. 4. Transition stages from the turf to the crust. (A-D) Material from incandescent light bulb found at Long Beach, WA, Dec 19, 2018. (E-G) Material from fluorescent tube found at Long Beach, WA, Nov 6, 2018. (A-E) Transverse sections showing the development of the mucilaginous perithallial layer. (A) Young crust with surface filaments (short arrow) and the initial generation of the secondary filaments from the basal layer (long arrow). (B) Basal layer cutting off cells and filaments that often undergo binary division (long arrow). (C) Developing crust with a short mucilaginous basal area and numerous surface filaments (short arrow). (D) Maturing crust with a thick mucilaginous perithallial matrix and sparse surface filaments. (E) Tubular appearance of mucilage in the perithallial layer. (F) Periclinal section of the matrix showing cells centrally located in the mucilaginous tubes. (G) Transverse section showing basal cells in mucilaginous tubes. Scale bars represent: A, B, D \& E, $50 \mu \mathrm{m} ; \mathrm{C}, 100 \mu \mathrm{m} ; \mathrm{F}, 20$ $\mu \mathrm{m} ; \mathrm{G}, 10 \mu \mathrm{m}$. 
in diameter, except for one $25 \mathrm{~cm}$ ball obtained shortly after our study was over. None of the balls had manufacturer markings on them. Originally made from recycled glass (often sake bottles), these fishing floats have not been used for commercial fishing in Japan for many years (Wood 1985), and they were very rare in the drift.

\section{Morphological observations of specimens in unialgal culture}

Spore germination and development. Spore germination observed in unialgal culture (JAW 4881) was similar to that observed in the original collections and then proceeded to develop into stages resembling the turf phase found in field material. In 1-2 weeks newly released spores elongated and divided transversely forming short filaments of 2-8 cells (2-7 $\mu$ m wide) (Fig. 5A). Intercalary cells in the filaments then divided transversally, longitudinally and obliquely, producing extensively branched monostromatic basal systems adhering to the glass (Fig. 5B). After four weeks, some of the crusts had reached 150 $\mu \mathrm{m}$ or more in overall size and were comprised of numerous cells (10 to hundreds). Random or clustered cell divisions parallel to the substrate resulted in upright shoots of significantly larger cells (6-15 $\mu \mathrm{m}$ diameter). Young filaments (4-6 cells) often contained a small basal cell (4-6 $\mu \mathrm{m})$ and a single enlarged apical cell, reminiscent of some turf filaments in field collections (Fig. 5A \& G, far right). As the crusts matured, numerous short ( 1 to a few cells) (Fig. 5C-E, on right) and long uniseriate erect filaments (up to $250 \mu \mathrm{m}$ long) (Fig. 5C \& F) developed. Occasionally, the filaments released vegetative cells as 'spores' (Fig. 5C \& H, arrows), similar in size to the original cells released when first placed into culture. Initially uniseriate, the upright filaments began to develop bi- to multiseriate packets in the uppermost part of the filaments (Fig. 5D \& H). As the monostromatic crusts expanded, new uprights were produced (Fig. 6A, arrow) and clusters of mature erect filaments became increasingly biseriate near their tips (Fig. 6B). Eventually, they began discharging their 'spores,' leaving behind the empty mucilaginous walls (Fig. 6C).

In culture, an additional pattern of 'spore' formation was observed. 'Giant cells,' obovate to irregular in shape (20-40 $\mu \mathrm{m}$ overall), were regularly produced by basal systems of variable sizes (Fig. 6D-F). These became multicellular and released internal autospores (Fig. 6G). This type of sporangial formation is different from that of typical filamentous Stylonematophyceae in which individual vegetative cells are released as spores from uni- to multi- seriate filaments.

DNA staining observations. SYBR Green staining clearly revealed the nucleus and numerous nucleoids in the plastid. Single cells (or spores) show numerous small (ca. 0.1-0.2 $\mu \mathrm{m}$ ) plastid nucleoids and a nucleus $(2-3 \mu \mathrm{m})$ in interphase (Fig. $6 \mathrm{H}$ ). In young multicellular (2 or more cells) stages, the staining showed nucleoids that were variable in numbers and position in the plastid (Fig. 6I). In cells before nuclear, plastid and cell division, nucleoids appeared to aggregate around the nucleus and were variable in size and shape (Fig. 6I, Supplementary Video S1).

\section{Molecular identification and the phylogenetic position of the new crust}

Although morphology was useful in confirming the probable occurrence of the new species, our final identifications were dependent on sequence data and phylogenetic reconstruction. By using $r b c \mathrm{~L}, p s b \mathrm{~A}$, and partial SSU, or the three genes combined, we determined that the turf and crustose thalli on the 12 glass debris items (9 collections) that we sequenced were all the same new species and that this species was different than T. transpacifica, the species isolated earlier from plastic debris (West et al. 2016). A summary of the glass and plastic specimens examined and their phylogenetic identifications is given in Supplementary Table S1. All genes analysed placed the new entity on glass in the Stylonematales and relationships within the Stylonematales were consistent with previous results (Zuccarello et al. 2008, West et al. 2016).

The 3-gene topology (Fig. 7) includes the holotype cultures of both T. transpacifica and the new species along with other samples, and it summarizes our phylogenetic observations. It clearly shows that $T$. transpacifica and the new species are independent from one another, and it supports their sister relationship. This sister relationship is also seen in the $p s b$ A (Supplementary Fig. S1) and SSU trees (Supplementary Fig. S2) but without support. However, the sister relationship is not seen in the $r b c \mathrm{~L}$ topology, the most taxon-rich of the individual gene analyses (Fig. 8).

Our sequenced samples included 12 different collections of the new species and 13 of T. transpacifica (Supplementary Table S1). The new species collections were derived from a wide variety of glass debris, shown in Fig 1. The sequences within this group were nearly identical. The T. transpacifica collections were derived from plastic debris, and were initially thought to consist of two 

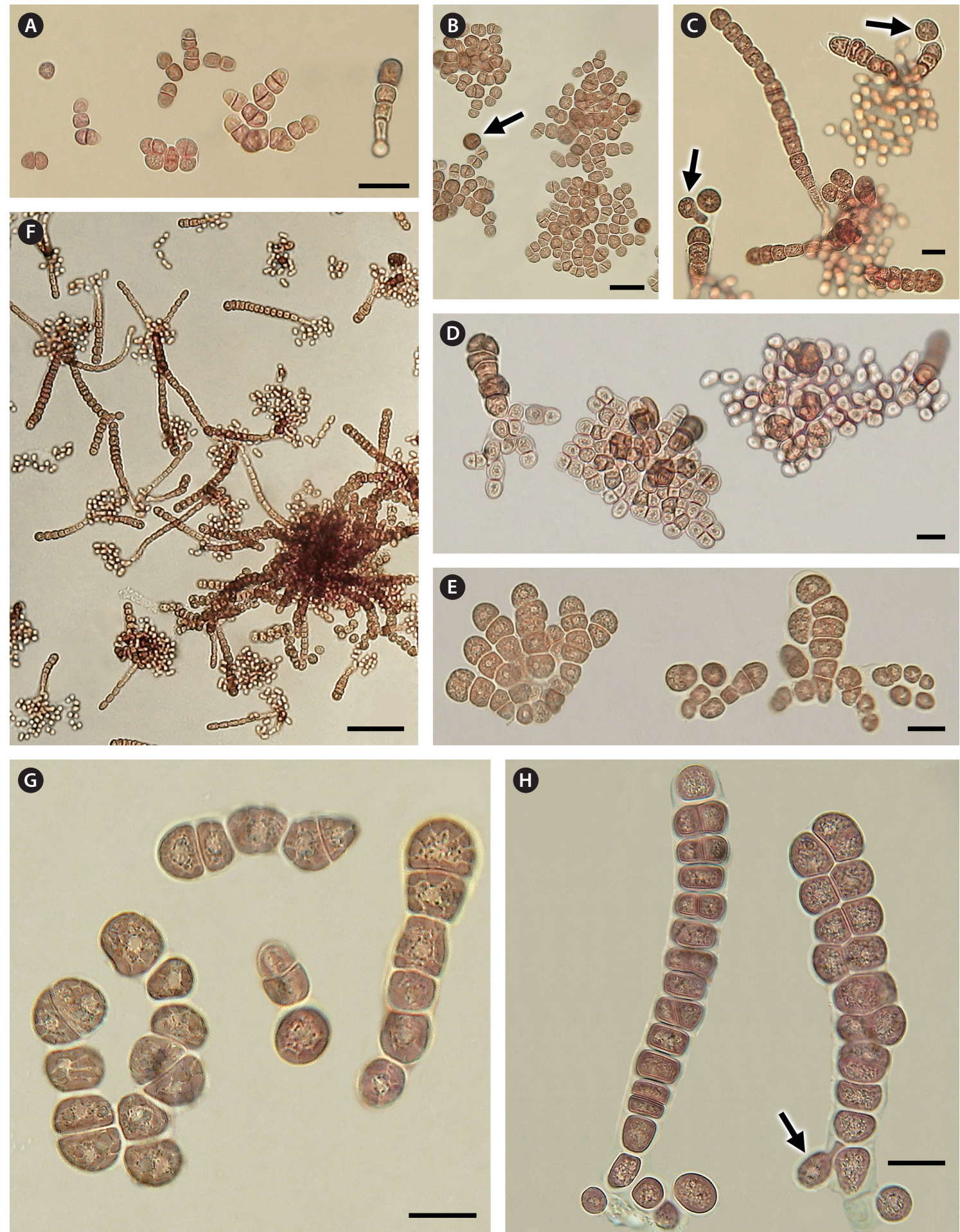

Fig. 5. Germination and growth of spores in culture 4881. (A) Early germination stages with basal layer of variably branched filaments; one young erect filament on right with large upper cell. (B) Basal layer with large cells (arrow) that initiate erect filaments. (C) Long erect uniseriate filament with large cells; shorter erect shoots with spore initiation and release (arrows). (D) Basal systems with single and multiple erect filaments; one erect shoot with oblique cell divisions. (E) Thallus sections with small basal cells and confluent erect filaments with larger cells. (F) Developmental variations in basal systems and erect filaments grown in shaker and bright light. (G) Large cells showing multilobed peripheral plastid and central nucleus surrounded by small granules. (H) Large-celled erect filaments with longitudinal and oblique cell divisions forming probable spores in upper $2 / 3$ of axes. On left, filament with 3 small basal cells. On right, with one lower cell (arrow) partially discharged as a spore. Scale bars represent: $A, 20 \mu \mathrm{m} ; \mathrm{B}, 15 \mu \mathrm{m} ; \mathrm{C}, \mathrm{D}, \mathrm{G} \& \mathrm{H}, 12 \mu \mathrm{m} ; \mathrm{E}, 14 \mu \mathrm{m} ; \mathrm{F}, 80 \mu \mathrm{m}$. 

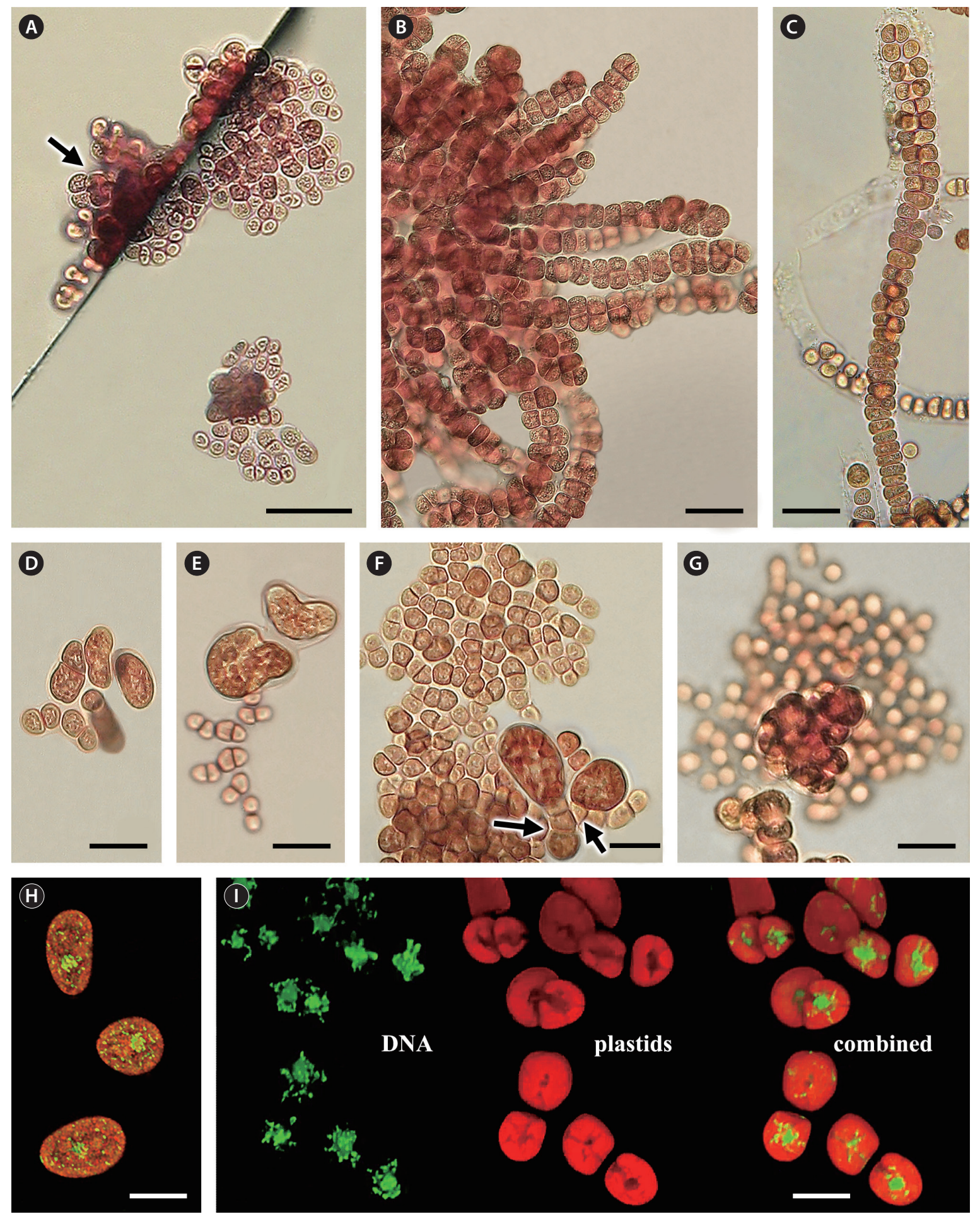

Fig. 6. Reproduction in culture 4881.9 and DNA characterization using SYBR Green. (A) Coverslip edge and flat surface showing single-celllayer basal system and new erect filament initiation (arrow). (B) Turf-like cluster of erect filaments with biseriate upper sections. (C) Filaments with spores beginning to discharge and the remains of the outer mucilaginous layer after spore release. (D \& E) Basal systems forming 'giant cells.' (F) Basal system with two 'giant cells' with one and three-celled stalks (arrows). (G) 'Giant cell' releasing spores. (H \& I) Confocal images of SYBR Green DNA stained cells. (H) Three single, undivided cells (spores?) each showing many scattered small nucleoids and an interphase nucleus. (I) Young, multi-cellular stage cells showing DNA (green) and red plastid autofluorescence, and a combined image. Staining reveals a single nucleus (2-3 $\mu \mathrm{m})$ and tiny odd-shaped (0.1-0.2 $\mu \mathrm{m})$ plastid nucleoids aggregated around nucleus. Scale bars represent: A, B \& D-G, $20 \mu \mathrm{m} ; \mathrm{C}, 50 \mu \mathrm{m} ; \mathrm{H}, 10 \mu \mathrm{m} ; \mathrm{l}$, $12 \mu \mathrm{m}$. 


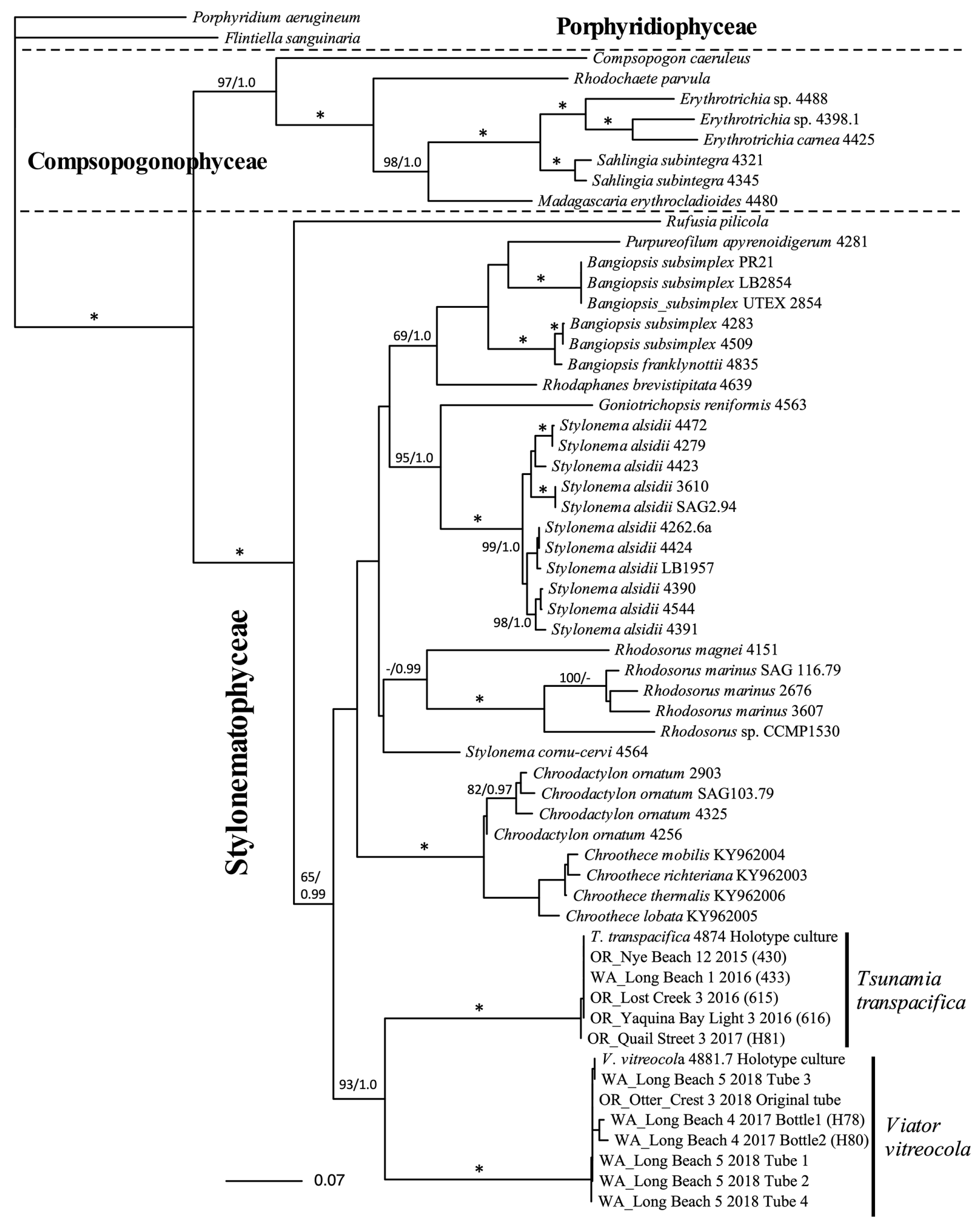

Fig. 7. Maximum-likelihood (ML) phylogenetic topology of 3 genes super matrix of various Porphyridiophyceae, Compsopogonophyceae and Stylonematophyceae. Both Viator vitreocola gen. et sp. nov. and Tsumania transpacifica are fully supported $\left(^{*}\right)$ by both ML bootstrap values (\%) and Bayesian posterior probabilities. The sister relationship of these two genera is well supported. Bootstrap values / posterior probabilities are on branches. Values below 50\% ML bootstrap and 0.9 / posterior probabilities are not shown. 


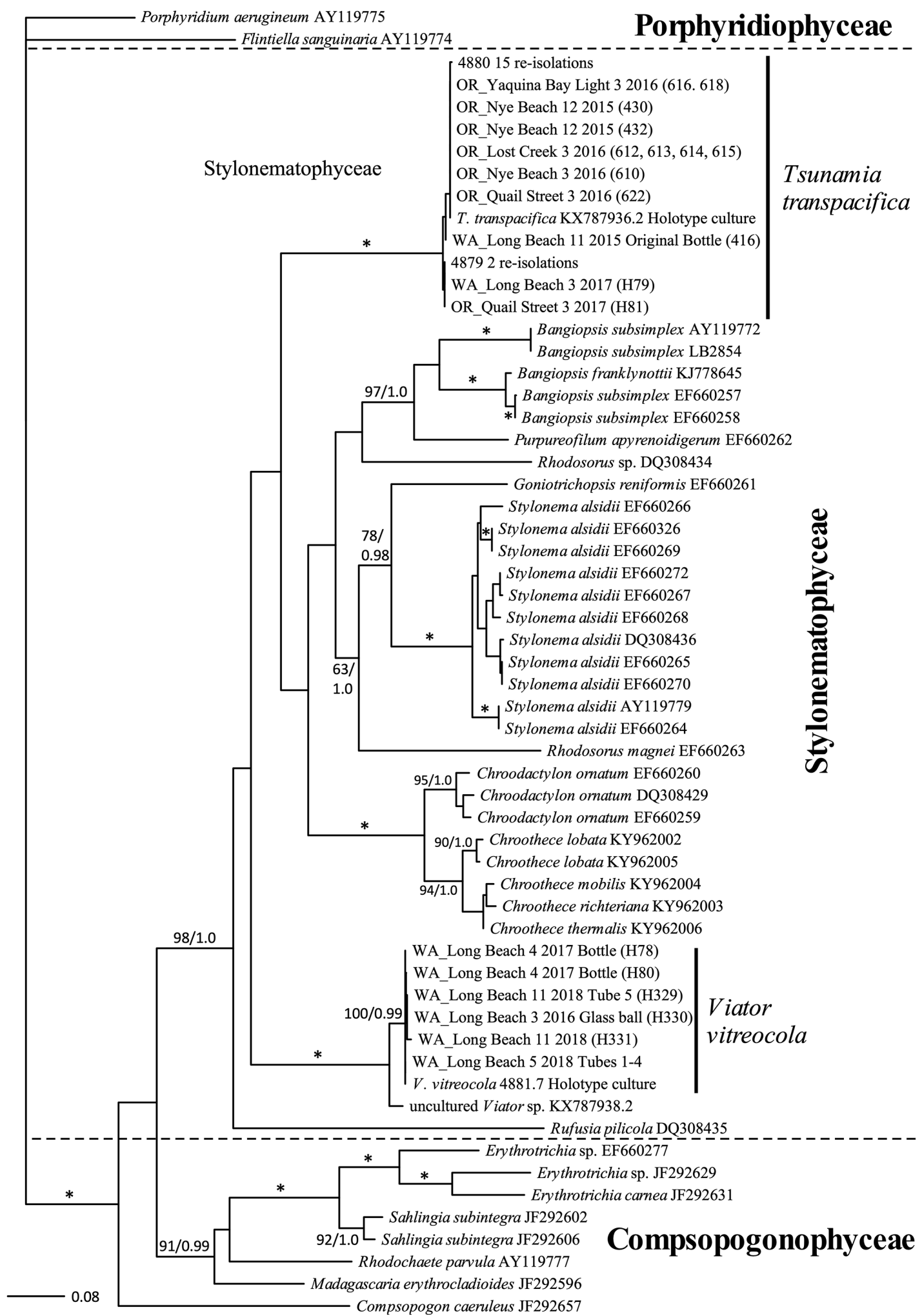

Fig. 8. Maximum-likelihood (ML) phylogenetic topology of $r b c L$ sequence data of various Porphyridiophyceae, Compsopogonophyceae and Stylonematophyceae. Both Viator vitreocola gen. et sp. nov. and Tsunamia transpacifica are fully supported (*) by both ML bootstrap values (\%) and Bayesian posterior probabilities. The sister relationship of these two genera is not supported. Uncultured Viator sp. (KX787938.2) is shown sister to V. vitreocola. Bootstrap values / posterior probabilities are on branches. Values below $50 \% \mathrm{ML}$ bootstrap and 0.9 / posterior probabilities are not shown. 
entities, true T. transpacifica and another entity which we called $r b c \mathrm{~L}$ sp. 2 (West et al. 2016, Table 1). The sequences from these collections were also found to be very similar. However, the $r b c \mathrm{~L}$ sp. 2 group appeared to also include a single sample that we initially called uncultured Stylonematales sp. in GenBank. We thought this sample was representative of the $r b c \mathrm{~L}$ sp. 2 group, but later we discovered that it was a contaminant with a very different sequence.

To investigate this further, we used our $r b c \mathrm{~L}$ sequences to carry out a pairwise comparison of the sequences of the prominent species and variants included in this study (Supplementary Table S3). The new species and the holotype of T. transpacifica were found to differ by 107$110 \mathrm{bp}$ with a similarity of only $85.4-85.8 \%$. T. transpacifica, including two samples of true $r b c \mathrm{~L}$ sp. 2, differed by $0-4 \mathrm{bp}$ and had a similarity of $99.6-100 \%$. Sequences of two collections of the new species were $100 \%$ similar. The contaminating sequence that we had originally called uncultured Stylonematales sp. was found to be most closely related to the new species, varying by only $13 \mathrm{bp}$, indicating a $98.3 \%$ similarity.

\section{Correcting the previous sequences of uncul- tured Stylonematales sp. in GenBank}

In the initial study of the debris crusts (West et al. 2016), we incorrectly assigned to T. transpacifica in GenBank, the $r b c \mathrm{~L}$ sequence of uncultured Stylonematales sp. (KX787936.1). To correct this, we have now assigned a new sequence based on the T. transpacifica holotype culture (KX787936.2). A second $r b c \mathrm{~L}$ sequence was assigned to uncultured Stylonematales sp. (KX787938.2), which we now recognize as "Uncultured Viator sp." This specimen could be a different strain or even a different species than the new species we are describing. However, since the specimen was a contaminant, we are uncertain of its origin and do not have enough material or information to investigate it further.

\section{Morphological and molecular conclusions}

Our examination of the new species on glass debris has shown that it is unique. It can be separated from $T$. transpacifica, its sister in the 3-gene phylogeny of the Stylonematales, not only by its sequences but also by its morphology and unusual habitat on floating glass debris in the Northeast Pacific. These and other differences (summarized in Supplementary Table S4) are great enough that we consider the species to be both a new ge- nus and species, and we propose the name, Viator vitreocola gen. et sp. nov.

\section{Viator Hansen, West and Zuccarello gen. nov.}

Description. A pale red alga found on floating debris that consists of two morphological phases: a loosely aggregated turf and a consolidated crust. Both phases are structurally composed of filaments lacking pit-plugs. The turf phase consists of small encrusting basal cells and numerous erect free filaments that may be uniseriate or multiseriate. The crust phase contains a basal layer of ellipsoidal to elongate cells, a mucilaginous perithallial layer of short filaments and cells often undergoing binary division, and a surface layer of free filaments. In both phases, reproduction occurs by the release of single cells as spores from the exposed erect and surface filaments. In juvenile thalli, autospores may also be produced. All cells contain a central nucleus, $2-3 \mu \mathrm{m}$ wide, and a single highly lobed parietal chloroplast without a pyrenoid.

Type species. Viator vitreocola Hansen, West and Zuccarello sp. nov.

Morphology. The young turf and mature crustose thalli occur on floating glass debris. In field collections, the pilose turf reaches up to $500 \mu \mathrm{m}$ in height and consists of a compact basal system of small cells, 4-8 $\mu \mathrm{m}$ in diameter, and numerous, occasionally branched, erect filaments, ranging in size from 4-7 um at their base to 15 $\mu \mathrm{m}$ near their rounded tips. Initially uniseriate, the erect filaments become increasingly bi- and multiseriate with age and release single cells as spores, 8-12 (15) $\mu \mathrm{m}$ in diameter. Cultured thalli display a developmental pattern that is similar to the turf phase, but, in addition, the basal systems can produce irregularly shaped 'giant cells' that form numerous internal autospores, 3-4 $\mu \mathrm{m}$ in diameter. In the field, consolidated crustose thalli develop from the maturing turf forms and reach $370 \mu \mathrm{m}$ or more in thickness. Each crust consists of a basal monostromatic layer of tightly appressed cells, a perithallus of loosely branched filaments immersed in a gelatinous matrix, and a surface layer of patchy, often spore-bearing free filaments up to 10 or more cells in length.

Etymology. V. vitreocola can be translated as a 'traveller on glass.' The name reflects its unusual habitat on floating glass debris.

Distribution. The species has been found on discarded fluorescent light tubes, incandescent light bulbs, glass liquor bottles, and ball-shaped fishing floats collected along the Northeast Pacific coast from Leadbetter Point State Park in Washington to Nye Beach in Oregon. 
Holotype. The cryopreserved culture JAW 4881.7.

Holotype locality. The holotype culture was obtained from a fluorescent tube collected by G. I. Hansen and SOLVE on the beach at Otter Crest, Lincoln County, Oregon, USA (44 $44.84^{\prime} \mathrm{N}, 124^{\circ} 3.89^{\prime} \mathrm{W}$ ) on Mar 25, 2018.

Holotype deposit. JAW 4881.7 has been accessioned as CCMP 3532 by the Provasoli-Guillard National Center for Marine Algae and Microbiota (NCMA), Bigelow Laboratory for Ocean Sciences, P.O. Box 380, 60 Bigelow Drive, East Boothbay, Maine 04544, USA (NCMA@bigelow.org).

Isotypes. The fluorescent tube from which the holotype culture was taken, OR_Otter_Crest 32018 (GIH 6433), was accessioned by the Oregon State University Herbarium, Corvallis (OSC-A-016618). Other isotypes are distributed at: National Herbarium of Victoria, Australia (MEL 2454713); University Herbarium of the University of California, Berkeley (UC 2076385); and University of Michigan Herbarium, Ann Arbor (MICH 701907).

GenBank accession numbers. $r b c \mathrm{~L}, \mathrm{MK} 775230 ; p s b \mathrm{~A}$, MK775210; SSU, MK775216.

\section{DISCUSSION}

\section{General characteristics of the Stylonematophy- ceae and Viator}

Viator vitreocola gen. et sp. nov. fits well within the Stylonematophyceae, a red algal class established by Yoon et al. (2006) that has been well-described (Yoon et al. 2010, Kamiya et al. 2017, Guiry and Guiry 2019). The species are typically simple in form, varying from unicells and colonies to prostrate and upright filamentous thalli lacking pit-plugs that have various plastid types (single multilobed or multiple discoid plastids, with or without a pyrenoid). Although most are marine, a few occur in freshwater or terrestrial habitats (e.g., Chroothece and Phragmonema). Some are unique to various substrates (e.g., algae, vascular plants, wood, plastics, and now glass). Complex and often unique extracellular mucilages are known in the group (Medcalf et al. 1981, Cabrera et al. 2014). Reproduction occurs through (1) cell division to produce spores in unicells and colonies or (2) in filamentous forms, the release of vegetative cells directly as monospores. In V. vitreocola, we also observed autospore formation in 'giant cells.' The only other Stylonematophycean known to form autospores is the unicellular Rhodospora sordida Geitler that produces 4-32 autospores from each cell (Ott 2009). Sexuality is not known in the class.

Two ultrastructural features characterize the Stylon- ematophyceae: (1) plastids (except Rhodaphanes) have a peripheral encircling thylakoid. This also occurs in the Florideophyceae and Compsopogonophyceae, but in other classes, the encircling thylakoid is absent. (2) Golgi bodies are associated with the endoplasmic reticulum. This characteristic is also seen in the Compsopogonophyceae, but, in other classes of the Rhodophyta, Golgi bodies are associated with mitochondria (Scott et al. 2010). The ultrastructure of V. vitreocola needs to be investigated to see if it also has these characteristics.

Possibly due to their small size and rarity, detailed information on a number of the Stylonematophyceae is still limited. Although many taxonomic studies have been published on the group (e.g., Garbary et al. 1981, West et al. 2005, 2007, 2014, 2016, Kikuchi et al. 2006, Zuccarello et al. 2008, 2009, Zheng and Li 2009, Kim and Kim 2011, Aboal et al. 2018), the descriptions of many of the species still lack molecular evidence, and obscure marine species have not been rediscovered for newer analyses (e.g., Colacodictyon, Empselium, Neevea, and Phragmonema). Often even the more recent descriptions are not thorough enough. In China, two genera, Stylonema and Chroodactylon, are known, but numerous new species have been described (Zheng and Li 2009) that still require more detailed anatomical / cytological study and molecular validation.

During this study, we obtained new information on the nuclei and plastid nucleoids in V. vitreocola using SYBR Green, a fluorescent stain that has been used in various Chlorophyta (Vitová et al. 2005). The stain worked well on our material, but the mitochondrial tracker JC-1 (Pendergrass et al. 2004) did not pass through the cell wall making it difficult to resolve which SYBR Green stained objects were mitochondria and which were nucleoids. The plastid nucleoids in $V$. vitreocola appeared to be 0.1-0.2 $\mu \mathrm{m}$ in their broadest dimension. To assess their size, we compared them to plastid nucleoids in other red algal species. In the Florideophyceae, the nucleoids in Polysiphonia confusa Hollenberg (=Eutrichosiphonia confusa (Hollenberg) A. M. Savoie \& G. W. Saunders) were shown to be 1-3 $\mu \mathrm{m}$ long in DAPI stained material (Coleman 1985). In the Rhodellophyceae, their size has been documented for 3 species. Using a Hoechst 33258 stain, nucleoids are shown to be 0.1-0.2 $\mu \mathrm{m}$ long in Corynoplastis japonica A. Yokoyama et al. and about $0.25 \mu \mathrm{m}$ in Neorhodella cyanea (C. Billard \& J. Fresnel) J. Scott et al. (Yokoyama et al. 2009). Using SYBR Green, Rhodella violacea (Kornmann) Wehrmeyer was found to have plastid "genophores" that are $0.25 \mu \mathrm{m}$ in diameter (Scott et al. 2011). The Rhodellophycean plastid nucleoids appear 
to be of similar size to those in V. vitreocola, but further analyses of the different cell cycle stages are necessary to clearly define their variation in size, number, and position within the plastid.

\section{Morphology and development of the Viator vitreocola gen. et sp. nov. thallus}

Although its basic features are typical of other Stylonematophyceae, V. vitreocola is unique in the class in its morphological complexity and development. The initial turf phase with its congested base and abundant erect filaments was not surprising since other morphologically simple red algae (e.g., some species in the Erythropeltidales and Acrochaetiales) also produce erect filaments from multicellular bases. However, the transformation into the complex morphology of the crust was unexpected. Although the 3-layered crust shares with some crustose Florideophyceae a basal layer lacking rhizoids, coherent erect filaments, and reproductive structures in upper filaments or nemathecia (e.g., Blinksia and some species of Peyssonnelia), the unusual structure and development of the perithallial layer in V. vitreocola is not known in any other red algal group.

The slow transformation between the two phases is particularly interesting because it appears to involve the rapid conversion of basal cells in the turf into closely aligned thick-walled ellipsoidal to elongate cells, similar to the cells that occur in Chroothece spp. (Aboal et al. 2018). In several Chroothece species, the cells produce mucilaginous stalks or tubes basally (underneath the parent cell) establishing short cushion-like colonies with the photosynthetic cells on the surface. In V. vitreocola, the basal cells appear to produce a mucilaginous tubular matrix apically as they concurrently cut off the binary cells and short filaments that make up the perithallus. As the crust develops, the internal filaments and mucilaginous tubes continue to grow, and the matrix thickens pushing up the original layer of turf filaments to the surface where they continue to produce spores and often erode. This unusual two-step pattern of development is not well understood. For Chroothece, Fritsch (1945) cites Pascher \& Petrova (1931) as reporting that the mucilage in this species is "secreted through numerous pores, which traverse the membranes and are especially abundant toward the poles." The production of cell mucilage in several Stylonematophyceae is also known to be related to the movement of cells, sometimes described as rapid and jerky (Fritsch 1945, Aboal et al. 2014), but there have been no additional studies on how the mucilage is produced.

\section{The habitat on floating debris}

Both V. vitreocola and T. transpacifica have been found on floating debris that washed ashore in Oregon and Washington, but the exact origin of the algae and their length of time at sea is unknown. As reported for T. transpacifica (West et al. 2016), the species could have settled on the debris either locally near their collection sites, in the open ocean, or perhaps in Asia and carried by currents to North America. Debris items from the Japanese tsunami of 2011 arrived on NE Pacific beaches from 1-5 years after the tsunami (Hansen et al. 2017, 2018), but other items have washed ashore after residing in the North Pacific Gyre for even longer periods of time (Howell et al. 2012, Maximenko et al. 2015). Authentic Japanese glass fishing-net floats, such as those found covered by $V$. vitreocola, are thought to have been in the ocean for 10 years or longer (Wood 1985). These floats were massproduced for Japan's deep-sea fisheries from 1910 to the 1940s when they were replaced by more resilient cork and aluminium floats and later by plastic. Thousands of the original glass floats are thought to still reside in the North Pacific Gyre (Wood 1985, Whitten 2012). Charles Moore, who is credited with discovering the Eastern Pacific Garbage Patch (Moore and Phillips 2012), estimates that, compared to plastics, glass floats of assorted size make up only about $1 \%$ of the flotsam in that area (C. Moore personal communication). The glass fishingnet floats and other debris, periodically blown out of the Gyre by storms, generally land on Washington and Oregon beaches during the winter and early spring (R. Lewis personal communication). The occurrence of algae on such long-term debris attests to the fact that adequate conditions for the growth and survival of these algae are available in the North Pacific.

Both species occurred on debris that floated on or near the surface where appropriate light for survival was available. T. transpacifica (West et al. 2016) was found only on buoyant high-density-polyethylene fragments $\sim 12 \mathrm{~cm}$ or longer in length (West et al. 2016). The size limit was puzzling to us, but the absence of the species on smaller plastic fragments, $\leq 1-2 \mathrm{~cm}$ in diameter, may be influenced by their greater instability in the water column. The glass items supporting V. vitreocola were always very buoyant and occurred at the surface. Both types of debris were subject to settlement by pelagic invertebrates (hydroids and Lepas anatifera Linnaeus), species that could grow large enough to cause the items to sink. Additional co-fouling was frequent on plastic, but on glass, it was very rare. Except for filamentous bacteria and diatoms, 
the extensive colonies of $V$. vitreocola nearly always occurred alone.

The absence of other algal species on the glass substrata is difficult to explain. It is possible that some of the items were only recently placed into the sea, not allowing adequate time for other colonization to take place. However, it is perhaps more likely that specific aspects of the glass surface prevented their settlement. The glass items that we examined were smooth and non-porous, features that could inhibit the attachment of other algal species. We had also expected to find herbivorous species like amphipods and gastropods, but none were present. With no other algal species competing for space and little impact from herbivory, $V$. vitreocola was easily able to spread out and dominate the glass debris. Its successful colonization of floating debris seemed to give this species the advantage of being able to disperse widely and increase its geographic range when appropriate habitats were available for settlement.

In her assessment of non-calcareous crustose red algae in the North Atlantic, Maggs (1990) suggested that the crustose habit restricts spore dispersal and that many red algal crusts do not grow on artificial substrata. V. vitreocola is one of the exceptions to this. Its frequent production of spores facilitates settlement and expansion on its own substratum, and we suspect that this also could assist it in colonizing other suitable habitats. Through our studies of V. vitreocola, T. transpacifica (West et al. 2016), the algae on Japanese tsunami debris (Hansen et al. 2017, 2018), and numerous algal surveys, we now know that a number of encrusting red algae do occur on artificial substrata and that some have been introduced, explaining their broad global distributions. When Carlton (1996) introduced the term 'cryptogenic' for widespread species with unknown origins, people immediately used this term to label widespread species without genetic records of their origins. This was also applied to many of the unicellular algae and encrusting forms with poorly known distributions. Cryptogenic red algal crusts are now listed in numerous surveys (e.g., Hewitt et al. 2004, Hansen et al. 2018).

\section{Geographic occurrence of the species}

In the Pacific, sequences of a number of Stylonematophyceae (West et al. 2005, 2007, 2014, 2016, Zuccarello et al. 2008) have given us a DNA framework to use for species identification, and they have also provided some insights into the distribution of the species. Within this group, a few species are regional, like V. vitreocola and
T. transpacifica, but often the species are very small and globally widespread. A recent distributional investigation of the widespread and microscopic Stylonema alsidii (Zanardini) K. M. Drew has shown that a wide variety of genotypes exist in this species worldwide and that, most often, they display no clear biogeographic pattern (Zuccarello et al. 2008). Similar widespread distributions with complex genetic variations are thought to occur in other small Stylonematophyceae, but within this class there are also a variety of species with narrow distributions due to their restrictive habitats. Examples of this would include: Rufusia pilicola Wujek \& Timpano, a species that grows only on the fur of sloths (Wujek and Timpano 1986), and Purpureofilum apyrenoidigerum, a species that is only known to occur epiphytically on mangrove algae (West et al. 2005).

V. vitreocola and T. transpacifica have only been found on floating debris, a habitat that does not seem to be biogeographically restrictive since it does occur globally. However, the only known occurrences of these two species are the shores of Oregon and Washington. Although both occur on debris that may have arisen in Asia, the species have not yet been found in Asia, in neighbouring areas around the North Pacific, or elsewhere globally. It is possible that in other areas the types of floating debris supporting these species have not been examined for fouling biota or that the species have been overlooked in possible 'natural habitats.' However, now that their habitat types and morphological features are known, it is likely that both species will soon be discovered in other areas expanding their biogeographic range.

\section{CONCLUSION}

The crustose red alga, $V$. vitreocola gen. et sp. nov., was found growing on floating glass debris that drifted ashore along the coasts of Oregon and Washington. DNA sequencing, culturing and anatomical study revealed that the alga was a member of the Stylonematophyceae and that it had a very unusual two-phase pattern of development. Both phases released single cells as spores, and juvenile stages of the alga also developed 'giant cells' that produced internal autospores. A 3-gene phylogeny revealed that the new species is sister to T. transpacifica, a species that occurs only on floating plastic debris. The two species differ in their sequences, morphology, and substrata, but they are both known from the same limited geographic region. With new descriptive information now available, it is likely that new discoveries will soon 
increase knowledge of their geographic range and also our understanding of their biology. Their occurrence on floating debris, an increasingly abundant global habitat, emphasizes the fact that our knowledge of many algae in the sea is far from complete and that new diversity remains to be discovered.

\section{ACKNOWLEDGEMENTS}

All authors contributed personal funding for this project, and additional help was provided by our various universities. GIH was given an outside worker laboratory at the US Environmental Protection Agency in Newport, Oregon. For culturing and photography, JAW and CDG were provided facilities and supplies at the University of Melbourne, made possible by Geoff McFadden. GCZ and HSY maintain laboratories at their universities and rely on various other funds for supplies and sequencing. HSY received partial funding from the National Research Foundation of Korea (NRF-2017R1A2B3001923). The SEM photograph was provided by Bill Rugh and Bonnie Smith of the US EPA. For the new genus and species, Michael Guiry provided a valuable exchange of ideas on the Latin name and also important nomenclatural advice. For accessioning herbarium specimens, we thank Mark Hurd for accessioning the holotype culture at CCMP, Bigelow Laboratory for Ocean Sciences, West Boothbay Harbor, Maine, and Melanie Link-Perez and Aaron Liston of OSC, Oregon State University at Corvallis, for accessioning the original fluorescent tube from which the holotype culture was taken. Also, Nimal Karunajeewa and Pina Milne (the Royal Botanical Gardens, Melbourne), Michael J. Wynne (University of Michigan, Ann Arbor), and Kathy Ann Miller (University Herbarium, University of California, Berkeley) were provided with isotype cultures of Viator vitreocola. We are particularly grateful to Russ Lewis and GRGG (the Grass Roots Garbage Gang) for their persistent efforts in collecting drift samples in Washington from 2013 to 2018. Marilyn Leary (Oregon State University) provided a drift incandescent lightbulb with the crust, and SOLVE (Stop Oregon Litter and Vandalism) gave us access to items collected during their 2018 Spring Oregon Beach Cleanup where the initial fluorescent tube was discovered.

\section{SUPPLEMENTAL MATERIAL}

Supplementary Table S1. Debris items from Wash- ington and Oregon with Stylonematophycean crusts (https://www.e-algae.org).

Supplementary Table S2. Summary of molecular data and models used for tree reconstructions (https:// www.e-algae.org).

Supplementary Table S3. Pairwise comparison of the $r b c \mathrm{~L}$ genes in Tsunamia and Viator species and variants investigated during this study (https://www.e-algae.org).

Supplementary Table S4. Characteristics of Tsunamia transpacifica and the phases of Viator vitreocola gen. et sp. nov. (https://www.e-algae.org).

Supplementary Fig. S1. Maximum-likelihood (ML) phylogenetic topology of the $p s b$ A sequence data of various Porphyridiophyceae, Compsopogonophyceae and Stylonematophyceae. Both Viator vitreocola gen. et sp. nov. and Tsumania transpacifica are fully supported $\left({ }^{*}\right)$ by both ML bootstrap values (\%) and Bayesian posterior probabilities. The sister relationship of these two genera is not supported. Bootstrap values / posterior probabilities are on branches. Values below 50\% ML bootstrap and 0.9 / posterior probabilities not shown (https://www.ealgae.org).

Supplementary Fig. S2. Maximum-likelihood (ML) phylogenetic topology of the SSU sequence data from various Porphyridiophyceae, Compsopogonophyceae and Stylonematophyceae. Both Viator vitreocola gen. et sp. nov. and Tsumania transpacifica are fully supported $\left({ }^{*}\right)$ by both ML bootstrap values (\%) and Bayesian posterior probabilities. The sister relationship of these two genera is not supported. Bootstrap values / posterior probabilities on branches. Values below 50\% ML bootstrap and 0.9 / posterior probabilities not shown (https:// www.e-algae.org).

Supplementary Video S1. SYBR Green DNA stained $V i$ ator cells in $360^{\circ}$ rotation. Left figure is SBYR Green staining of whole cells with plastid autofluorescence, central figure is the SYBR stain of nuclear, plastid and mitochondrial DNA, and right figure is only plastid autofluorescence (https://www.e-algae.org).

\section{REFERENCES}

Aboal, M., Chapuis, I., Paiano, M., Sánchez, P., West, J. A., Whitton, B. A. \& Necchi, O. Jr. 2018. Diversity of Chroothece (Rhodophyta, Stylonematales) including two new species. Eur. J. Phycol. 53:189-197.

Aboal, M., García-Fernández, M. E., Roldán, M. \&Whitton, B. A. 2014. Ecology, morphology and physiology of Chroothece richteriana (Rhodophyta, Stylonematophyceae) in 
the highly calcareous Río Chícamo, south-east Spain. Eur. J. Phycol. 49:83-96.

Andersen, R. A. 2005. Algal culturing techniques. Elsevier, Amsterdam, $578 \mathrm{pp}$.

Broom, J. E., Jones, W. A., Hill, D. F., Knight, G. A. \& Nelson, W. A. 1999. Species recognition in New Zealand Porphyra using 18S rDNA sequencing. J. Appl. Phycol. 11:421-428.

Cabrera, J. M., Stortz, C. A. \& Rodríguez, M. C. 2014. A sulfated galactan from the mucilaginous sheath of the red filamentous alga Chroodactylon ornatum (Stylonematophyceae, Rhodophyta). J. Appl. Phycol. 26:1801-1811.

Carlton, J. T. 1996. Biological invasions and cryptogenic species. Ecology 77:1653-1655.

Carlton, J. T., Chapman, J. W., Geller, J. B., Miller, J. A., Carlton, D. A., McCuller, M. I., Treneman, N. C., Steves, B. P. \& Ruiz, G. M. 2017. Tsunami-driven rafting: transoceanic species dispersal and implications for marine biogeography. Science 357:1402-1406.

Coleman, A. W. 1985. Diversity of plastid DNA configuration among classes of eukaryote algae. J. Phycol. 21:1-16.

Freshwater, D. W. \& Rueness, J. 1994. Phylogenetic relationships of some European Gelidium (Gelidiales, Rhodophyta) species, based on $r b c \mathrm{~L}$ nucleotide sequence analysis. Phycologia 33:187-194.

Fritsch, F. E. 1945. The structure and reproduction of the algae. Vol. II. Foreword, Phaeophyceae, Rhodophyceae, Myxophyceae. Cambridge University Press, Cambridge, 939 pp.

Garbary, D. J., Hansen, G. I. \& Scagel, R. F. 1981. The marine algae of British Columbia and northern Washington: Division Rhodophyta (red algae), Class Bangiophyceae. Syesis 13:137-195.

Guiry, M. D. \& Guiry, G. M. 2019. AlgaeBase. World-wide electronic publication, National University of Ireland, Galway. Available from: http://www.algaebase.org. Accessed Feb 2, 2019.

Hansen, G. I., Hanyuda, T. \& Kawai, H. 2017. Benthic marine algae on Japanese tsunami marine debris: a morphological documentation of the species. Part 1. The tsunami event, the project overview, and the red algae. OSU Scholars Archive, Corvallis, OR, 50 pp.

Hansen, G. I., Hanyuda, T. \& Kawai, H. 2018. Invasion threat of benthic marine algae arriving on Japanese tsunami marine debris in Oregon and Washington, USA. Phycologia 57:641-658.

Hewitt, C. L., Campbell, M. L., Thresher, R. E., Martin, R. B., Boyd, S., Cohen, B. F., Currie, D. R., Gamon, M. F., Keough, M. J., Lewis, J. A., Lockett, M. M., Mayes, N., McArthur, M. A., O'Hara, T. D., Poore, G. C. B., Ross, D. J., Storey, M. J., Watson, J. E. \& Wilson, R. S. 2004. Introduced and cryptogenic species in Port Phillip Bay, Victoria, Australia. Mar. Biol. 144:183-202.

Howell, E. A., Bograd, S. J., Morishige, C., Seki, M. P. \& Polovina, J. J. 2012. On North Pacific circulation and associated marine debris concentration. Mar. Pollut. Bull. 65:16-22.

Kamiya, M., Lindstrom, S. C., Nakayama, T., Yokoyama, A., Lin, S. -M., Guiry, M. D., Gurgel, F. D. G., Huisman, J. M., Kitayama, T., Suzuki, M., Cho, T. O. \& Frey, W. 2017. Rhodophyta. In Frey, W. (Ed.) Syllabus of Plant Families. 13th ed. Part 2/2 Photoautotrophic Eukaryotic Algae. Borntraeger Science Publishers, Stuttgart, pp. 1-171.

Kikuchi, N., West, J. A., Kajimura, M. \& Shin, J. A. 2006. Goniotrichopsis reniformis (Kajimura) Kikuchi comb. nov. (Stylonematales, Rhodophyta) from Japan. Algae 21:185-191.

Kim, H. -S. \& Kim, S. -M. 2011. Algal flora of Korea. Vol. 4, No. 1. Rhodophyta: Stylonematophyceae, Compsopogonophyceae, Bangiophyceae. Primitive red algae. National Institute of Biological Resources, Incheon, $138 \mathrm{pp}$.

Maggs, C. A. 1990. Distribution and evolution of non-coralline crustose red algae in the North Atlantic. In Garbary, D. J. \& South, G. R. (Eds.) Evolutionary Biogeography of the Marine Algae of the North Atlantic. NATO ASI Series G: Ecological Sciences 22. Springer-Verlag, Berlin, pp. 241-264.

Maximenko, N., MacFadyen, A. \& Kamachi, M. 2015. Modeling the drift of marine debris generated by the 2011 tsunami in Japan. PICES Press 23:32-36.

Medcalf, D. G., Brannon, J. H., Scott, J. R., Allen, G. G., Lewis, J. \& Norris, R. E. 1981. Polysaccharides from microscopic red algae and diatoms. Proc. Int. Seaweed Symp. 8:582-588.

Moore, C. \& Phillips, C. 2012. Plastic ocean: how a sea captain's chance discovery launched a determined quest to save the oceans. Penguin Books Ltd., London, 368 pp.

Ott, F. D. 2009. Handbook of the taxonomic names associated with the non-marine Rhodophycophyta. J. Cramer, Stuttgart, $969 \mathrm{pp}$.

Pascher, A. \& Petrova, J. 1931. Über Porenapparate und Bewegung bei einer neuen Bangiale (Chroothece mobilis). Archiv Protistenk. 74:490-522.

Pendergrass, W., Wolf, N. \& Poot, M. 2004. Efficacy of MitoTracker Green ${ }^{\mathrm{TM}}$ and CMXrosamine to measure changes in mitochondrial membrane potentials in living cells and tissues. Cytometry A 61:162-169.

Ronquist, F. \& Huelsenbeck, J. P. 2003. MrBayes 3: Bayesian phylogenetic inference under mixed models. Bioinformatics 17:1572-1574.

Ronquist, F., Teslenko, M., van der Mark, P., Ayres, D. L., Dar- 
ling, A., Höhna, S., Larget, B., Liu, L., Suchard, M. A. \& Huelsenbeck, J. P. 2012. MrBayes 3.2: efficient Bayesian phylogenetic inference and model choice across a large model space. Syst. Biol. 61:539-542.

Saunders, G. W. \& Kraft, G. T. 1994. Small-subunit rRNA gene sequences from representatives of selected families of the Gigartinales and Rhodymeniales (Rhodophyta). 1. Evidence for the Plocamiales ord. nov. Can. J. Bot. 72:1250-1263.

Scott, J. L., Orlova, E. \& West, J. A. 2010. Ultrastructural observations of vegetative cells of two new genera in the Erythropeltidales (Compsopogonophyceae, Rhodophyta): Pseudoerythrocladia and Madagascaria. Algae 25:11-15.

Scott, J., Yang, E. C., West, J. A., Yokoyama, A., Kim, H. J., Loiseaux de Goër, S., O’Kelly, C. J., Orlova, E., Kim, S. Y., Park, J. K. \& Yoon, H. S. 2011. On the genus Rhodella, the emended orders Dixoniellales and Rhodellales with a new order Glaucosphaerales (Rhodellophyceae, Rhodophyta). Algae 26:277-288.

Trifinopoulos, J., Nguyen, L. -T., von Haeseler, A. \& Minh, B. Q. 2016. W-IQ-TREE: a fast-online phylogenetic tool for maximum likelihood analysis. Nucleic Acids Res. 44:W232-W235.

Vitová, M., Hendrychová, J., Cepák, V. \& Zachleder, V. 2005. Visualization of DNA-containing structures in various species of Chlorophyta, Rhodophyta and Cyanophyta using SYBR Green I dye. Folia Microbiol. 50:333-340.

West, J. A., de Goër, S. L. \& Zuccarello, G. C. 2014. A new species of Bangiopsis: B. franklynottii sp. nov. (Stylonematophycae, Rhodophyta) from Australia and India and comments on the genus. Algae 29:101-109.

West, J. A., Hansen, G. I., Hanyuda, T. \& Zuccarello, G. C. 2016. Flora of drift plastics: a new red algal genus, Tsunamia transpacifica (Stylonematophyceae) from Japanese tsunami debris in the northeast Pacific Ocean. Algae 31:289-301.

West, J. A. \& McBride, D. L. 1999. Long-term and diurnal carpospore discharge patterns in the Ceramiaceae, Rhodomelaceae and Delesseriaceae (Rhodophyta). Hydrobiologia 398/399:101-113.

West, J. A., Zuccarello, G. C., Scott, J., Pickett-Heaps, J. \& Kim, G. H. 2005. Observations on Purpureofilum apyrenoidigerum gen. et sp. nov. from Australia and Bangiopsis subsimplex from India (Stylonematales, Bangiophyceae, Rhodophyta). Phycol. Res. 53:49-66.

West, J. A., Zuccarello, G. C., Scott, J. L., West, K. A. \& Karsten, U. 2007. Rhodaphanes brevistipitata gen. et sp. nov., a new member of the Stylonematophyceae (Rhodophyta). Phycologia 46:440-449.

Whitten, D. 2012. Glass bottle marks. Glass fishing net floats. Available from: https://www.glassbottlemarks.com/ glass-fishing-net-floats/. Accessed Apr 8, 2019.

Wood, A. L. 1985. Beachcombing for Japanese glass floats. 4th ed. Binford \& Mort Publishing, Portland, OR, 266 pp.

Wujek, D. E. \& Timpano, P. 1986. Rufusia (Porphyridiales, Phragmonemataceae), a new red alga from sloth hair. Brenesia 25/26:163-168.

Yokoyama, A., Scott, J. L., Zuccarello, G. C., Kajikawa, M., Hara, Y. \& West, J. A. 2009. Corynoplastis japonica gen. et sp. nov. and Dixoniellales ord. nov. (Rhodellophyceae, Rhodophyta) based on morphological and molecular evidence. Phycol. Res. 57:278-289.

Yoon, H. S., Hackett, J. D., Pinto, G. \& Bhattacharya, D. 2002. The single, ancient origin of chromist plastids. Proc. Natl. Acad. Sci. U. S. A. 99:15507-15512.

Yoon, H. S., Müller, K. M., Sheath, R. G., Ott, F. D. \& Bhattacharya, D. 2006. Defining the major lineages of red algae (Rhodophyta). J. Phycol. 42:482-492.

Yoon, H. S., Zuccarello, G. C. \& Bhattacharya, D. 2010. Evolutionary history and taxonomy of red algae. In Seckbach, J. \& Chapman, D. J. (Eds.) Red Algae in the Genomic Age. Vol. 13. Cellular Origin, Life in Extreme Habitats and Astrobiology. Springer, New York, pp. 27-42.

Zheng, B. F. \& Li, J. 2009. Flora algarum marinarum sinicarum, Tomus II, Rhodophyta No. I. Porphyridiales, Erythropeltidales, Goniotrichiales, Bangiales. Science Press, Beijing, 134 pp.

Zuccarello, G. C. \& Lokhorst, G. M. 2005. Molecular phylogeny of the genus Tribonema (Xanthophyceae) using $r b c \mathrm{~L}$ gene sequence data: monophyly of morphologically simple algal species. Phycologia 44:384-392.

Zuccarello, G. C., Oellermann, M., West, J. A. \& De Clerck, O. 2009. Complex patterns of actin molecular evolution in the red alga Stylonema alsidii (Stylonematophyceae, Rhodophyta). Phycol. Res. 57:59-65.

Zuccarello, G. C., Sandercock, B. \& West, J. A. 2002. Diversity within red algal species: variation in world-wide samples of Spyridia filamentosa (Ceramiaceae) and Murrayella periclados (Rhodomelaceae) using DNA markers and breeding studies. Eur. J. Phycol. 37:403-417.

Zuccarello, G. C., West, J. A. \& Kikuchi, N. 2008. Phylogenetic relationships within the Stylonematales (Stylonematophyceae, Rhodophyta): biogeographic patterns do not apply to Stylonema alsidii. J. Phycol. 44:384-393. 